\title{
MAPPING HUMAN MOVEMENT USING STABLE OXYGEN ISOTOPIC RATIO MASS SPECTROMETRY: POTENTIAL APPLICATION TO FORENSIC SCIENCE DEMONSTRATED BY A MODERN HORSE-HUMAN STUDY
}

\author{
L.S. BELL ${ }^{1}$, J.A LEE-THORP ${ }^{2}$, AND K. DOBNEY ${ }^{3}$
}

\begin{abstract}
The utility of stable oxygen isotope analysis for demonstrating human migration has been developed and demonstrated on archaeological human populations. The application of this approach to tracking human movement has seldom been applied within forensic science. This paper gives results from a stable oxygen isotope assessment of extant modern human and horse enamel $\delta^{18} \mathrm{O}$ values recovered from tooth enamel. The human and horses were all constrained to known geographic locales for the period of tooth formation and compared to UK and global precipitation values for $\delta^{18} \mathrm{O}$. It was found that human and horse values track one another and horse can be used with some confidence as a human proxy. UK values were constrained geographically and outlier values to the UK were identified between Iceland and the Sudan. For application within the realm of forensic science more research is required to understand the regionalized contribution of hydrology to a catchment and the potentially confounding contribution of mixed water sources. However, as a tool to track human movement within forensics there is clear utility.
\end{abstract}

\section{RÉSUMÉ}

L'utilisation de l'analyse d'isotope d'oxygène stable pour démontrer la migration humaine a été développée et démontrée sur les populations archéologiques. L'utilisation de cette technique pour retrouver la trace de personnes n'a été que très peu appliquée dans le domaine des sciences judiciaires. La présente recherche porte sur les résultats d'une évaluation d'isotope d'oxygène stable provenant de l'émail des dents d'humains modernes et de cheveaux avec des valeurs de $\delta^{18} 0$. Les humains et les chevaux se trouvaient tous dans des endroits géographiques connus lors de la période de formation des dents, et ils ont été comparés à des valeurs de précipitation de $\delta^{18} \mathrm{O}$ pour le Royaume-Uni et à l'échelle mondiale. On a constaté que les valeurs pour les humains et les cheveaux se valaient, et qu'on pouvait substituer de façon fiable le cheval à l'humain. Les résultats obtenus au Royaume-Uni proviennent de lieux géographiques précis. D’autres résultats en dehors du Royaume-Uni ont été obtenus en comparant les données de l'Islande et celles du Soudan. Avant l'application de cette technique à des fins judiciaires, il est nécessaire de faire plus de recherches afin de comprendre l'influence de l'hydrologie régionale sur les plans d'eau et le facteur potentiellement confondant des sources d'eau mélangées. Cependant, son utilité en tant que technique judiciaire pour retracer les déplacements humains ne fait aucun doute.

1. School of Criminology, Simon Fraser University, 8888 University Drive, Burnaby, B.C., V5A 1S6, Canada. Email: lynneb@sfu.ca. To whom correspondence should be addressed.

2. Dept. Archaeology, University of Bradford, Bradford, West Yorks., BD7 1DP, U.K.

3. Dept. Archaeology, University of Durham, South Road, Durham, DH1 3LE, U.K. 


\section{INTRODUCTION}

The notion that human geographic movement may be tracked using stable light isotopic analysis of skeletal material has been an area of investigation ongoing in archaeology. This area of research has been little developed or applied to forensic questions regarding human movement. It does however, have application towards aiding human identification of skeletal remains and for further development on the living for tracking issues concerning national security.

The key elements investigated and utilized for migration studies in archaeology have included lead, strontium $(1,2)$ and more recently oxygen $(3-5)$. These elements have been recovered from the mineral portion of bone and teeth and more usually from enamel. Enamel being almost entirely composed of mineral has been demonstrated to be more resistant to diagenetic alteration over time and differing depositional contexts (6-9). Dietary isotopic elements might also be utilized for dietary reconstruction work in the context of mapping movement, where a marked $\mathrm{C}_{4}$ signal might be detected in bone or dentine collagen in a $\mathrm{C}_{3}$ locale (10). However, this type of signature is geographically crude as an indicator of movement, but one that might be usefully exploited amongst other isotopic signatures. New methodologies concerning temporal sampling of the incremental tissues of bone and teeth have been developed (11-13) including the recovery of bone collagen formed close to death (14).

Oxygen stable light isotope analysis represents the most recent and significant step toward mapping human movement. This isotopic signature may be derived from either the phosphate or carbonate compartments of mammalian bioapatite (15). The recovery of phosphate derived $\delta^{18} \mathrm{O}$ was developed originally to access palaeoclimate temperature data stored in fossil mammal teeth (16-19), whilst other studies have employed carbonate derived $\delta^{18} \mathrm{O}(20,21)$. The drinking water intake of mammals contains $\delta^{18} \mathrm{O}$ values which are derived from average precipitation (rain water), which in turn contributes to ground water values $(22,23)$. These values change as a weather system crosses a landmass, since repeated rain-out events cause fractionation of ${ }^{18} \mathrm{O} /{ }^{16} \mathrm{O}$ so that precipitation becomes relatively enriched or depleted. Factors which are influential are the origin of a weather system itself, temperature, humidity and global latitude (24). Other factors which might contribute to fractionation are topographical. Mountainous ranges, for example, cause substantive temperature changes, as do larger-scale continental temperature changes (22). For the UK, the majority of weather sweeps in from the Atlantic and creates a vertical north south distribution of $\delta^{18} \mathrm{O}$ values for precipitation $(23,25-27)$, as illustrated in Figure 1. Other smaller contributions to $\delta^{18} \mathrm{O}$ values concern oxygen derived from food intake and also how frequently - on a daily basis - a mammal drinks water (15).

Studies which have employed $\delta^{18} \mathrm{O}$ values from tooth enamel itself to map human movement have utilized this temperature related fractionation effect on precipitation, and hence drinking water consumed by mammals, to demonstrate geographic locale at the time of tooth or bone formation, rather than for reconstruction of past palaeotemperature $(3,4,28)$. However, one of the difficulties and challenges for deep time studies, or even studies that concern the past 10,000 years, is the effect of climate change on regionalized hydrology. For instance, aquifers and glacial melt water contain waters which are of mixed ages and therefore potentially differing $\delta^{18} \mathrm{O}$ values $(29,30)$ to that of localized precipitation. In a modern context, climate change is more precisely monitored and regionally $\delta^{18} \mathrm{O}$ values are measured seasonally; in some areas of the world they have been collected for 20 years or more (GNIP database). Localized contributions from aquifers and glacial runoff may also be monitored and factored into any regional effects $(22,31,32)$. This effectively means that this form of human tracking may be more precisely applied and further 


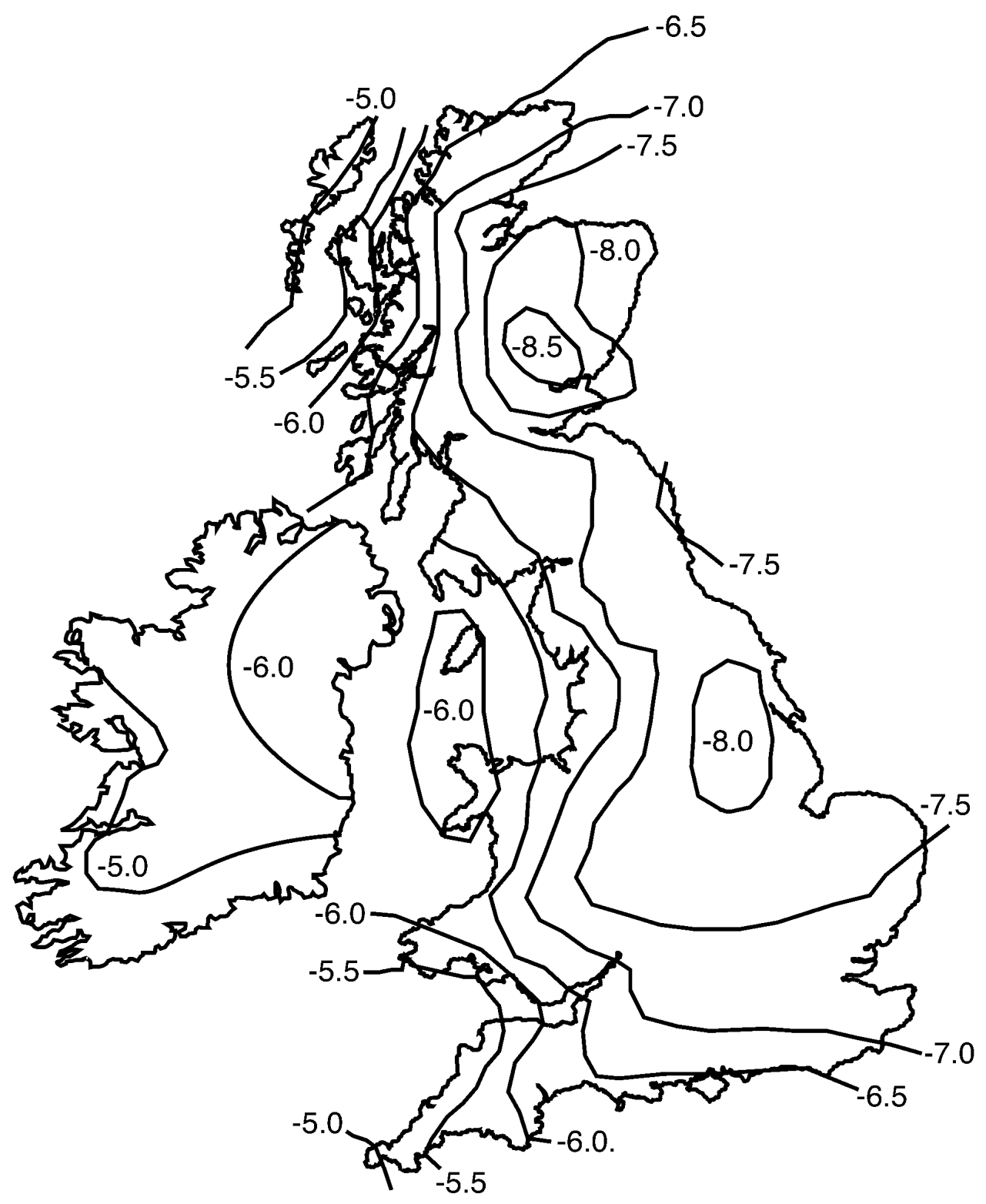

Figure 1. Country-wide distribution schema of annual mean precipitation values for the U.K. based on a composite of Darling et al.'s work (23,25-27).

developed within the realm of forensics, which for the most part, concerns cases no older than 50 years, and can utilize modern climate and hydrological data.

The aim of this study was to examine broadly the usefulness of stable oxygen in a modern context and was threefold. The first objective was to establish that mammalian $\delta^{18} \mathrm{O}$ values do actually track latitudinal values for rain water between Iceland and the Sudan and to identify outlier values for the UK. The second was to use this horse transect to parameterize U.K. values for $\delta^{18} \mathrm{O}$. And finally, the study sought to compare extant $\delta^{18} \mathrm{O}$ human U.K. values to that of the horse values to evaluate horse as a potential human proxy. 


\section{MATERIAL AND METHODOLOGY}

Modern horse molars and human molar orthodontic extractions were collected for this study. The horse teeth were drawn from geographical locations where horse life history was known during the period of formation of those teeth sampled. Human teeth were collected from colleagues at the Natural History Museum in London and were composed of childhood extractions which had been retained. These teeth were donated to the study and the geographical location of staff was documented for the period of crown formation.

The horses' geographical locations were recorded at latitudinally descending locales extending from Iceland, UK, Spain, Greece, Aden to the Sudan and were from lowland locations to avoid any altitude-temperature effects. The geographical locale for human teeth was constrained to the U.K. during the period of crown formation.

Horse teeth were physically sampled using a diamond tipped rotary burr and small amounts of enamel powder were removed from each tooth below the cusp and margin and away from any evidence of white spot lesion, overt caries and dental calculus. In addition, an initial light abrasion of the surface area was undertaken to remove the surface layer as a method of cleaning. Human teeth were similarly sampled and the enamel powder retained. Enamel powders were prepared after Lee-Thorp et al. (20). Approximately $1 \mathrm{mg}$ of treated material was weighed into glass vials and introduced into a Kiel carbonate device connected to the Finnigan-Mat 252 ratio mass spectrometer. Ratio determinations of the relative abundance of ${ }^{18} \mathrm{O} /{ }^{16} \mathrm{O}$ were expressed relative to the Belemnitella Americana from the Cretaceous Peedee formation (PDB) standard with a precision of $\pm 0.1 \%$.

\section{RESULTS}

The results from the horse study are given in Table 1 and graphically illustrated in Figure 2. The $\delta^{18} \mathrm{O}$ values for horse enamel are seen to become more positive or enriched along the latitudinal North-South horse transect. This study confirms that the latitudinal precipitation values are stored in horse enamel. The horse $\delta^{18} \mathrm{O}$ values, expressed as PDB, closely compare to Vienna Standard Mean Ocean Water (VSMOW) values for precipitation. Hence, the Icelandic horse enamel value is seen as $-10.2 \delta^{18} \mathrm{O}$ PDB and the average annual precipitation value for Iceland is $-10.0 \delta^{18} \mathrm{O}$ VSMOW. The horse values for the U.K. range were found to be between -7.2 to $-4.8 \delta^{18} \mathrm{O}$ and fit within the mapped precipitation values for the UK (Figure 1). Whilst it is not recommended to mix scales when comparing data, there is some utility to making this relative comparison in this instance. This curious relationship of relative comparability, whilst it is not the subject of this study, does allow for PDB and VSMOW values to be read together. This study has demonstrated the close, albeit relative, relationship between these two standards for mammal bioapatite and water derived $\delta^{18} \mathrm{O}$ values from a geographical perspective alone. If the mammal PDB values were required in VSMOW then a simple conversion equation may be applied.

The human tooth enamel results are given in Table 2 and are represented graphically in Figure 2. The human teeth were drawn from individuals who were living in the UK during the period of formation of their teeth and the results give a range of -5.3 to $-7.1 \delta^{18} \mathrm{O}$. The human and horse values can be seen to be similarly constrained for the UK. No depleted or enriched values were seen in the human group that tracked or compared to the horse values recorded existing outside of the UK. The range for horse and human $\delta^{18} \mathrm{O}$ values collectively is -7.2 to $-4.8 \delta^{18} \mathrm{O}$. This is the observed range upon which human values may be constrained for the UK. Figure 2 illustrates the relationship between locale and latitude, and horse and human values for the UK are seen to cluster. The value $-4 \delta^{18} \mathrm{O}$ PDB has been here given as a hypothetical cut-off for UK's most relatively enriched southern 
TABLE 1.

\section{HORSE STUDY}

Extant modern lowland horse $\delta^{18} \mathrm{O}$ PDB values for enamel and their latitudinal global locale.

\begin{tabular}{llrc}
\hline UCT no & Locale & $\delta^{18} \mathrm{O}$ & Latitude \\
\hline 7596 & Iceland & -10.2 & 65 \\
7593 & Nora, Shetland & -6.0 & 61 \\
7581 & Eriskay, Scotland & -5.1 & 57 \\
7565 & Eriskay & -7.2 & 57 \\
7587 & Celtic pony, unk & -4.9 & 56 \\
7589 & Celtic pony, unk & -4.8 & 56 \\
7603 & Arch, Belgium RM & -5.7 & 52 \\
7572 & Exmoor, UK & -5.9 & 51 \\
7570 & New Forest, UK & -4.8 & 50.5 \\
7571 & New Forest, UK & -5.4 & 50.5 \\
7564 & Pindos, Greece & -3.9 & 39.5 \\
7600 & Donana, S Spain & -2.9 & 37 \\
7602 & Donana, S Spain & -1.1 & 37 \\
7575 & Sarham, Aden & -1.8 & 14 \\
7578 & Socotra, Indian Ocean & 0.6 & 13 \\
\hline
\end{tabular}

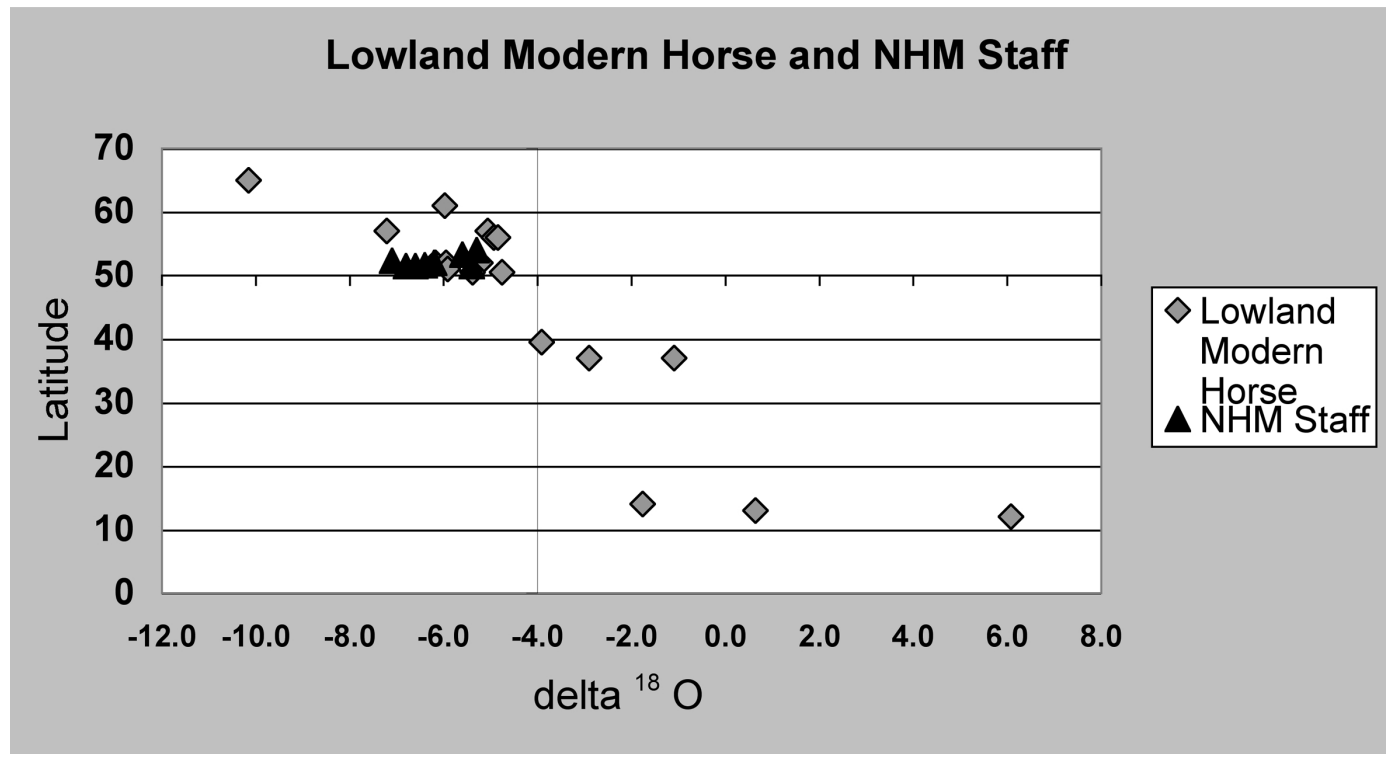

Figure 2. Extant modern horse - human $\delta^{18} \mathrm{O}$ PDB values for enamel and their geographical locale given against latitude.

value. A northerly cut-off might be given as $-8.5 \delta^{18} \mathrm{O}$ PDB based on precipitation data illustrated in Figure 1.

\section{DISCUSSION AND CONCLUSION}

The horse-human study revealed that a large-scale latitudinal relationship between mammalian enamel $\delta^{18} \mathrm{O}$ values does exist and that this relationship may be tracked spatially along a global latitudinal gradient. Further, the values observed for the UK are here constrained between -8.5 to $-4.0 \delta^{18} \mathrm{O}$. Whilst not understood, the PDB standard builds in 


\section{HUMAN STUDY}

Extant modern human $\delta^{18} \mathrm{O}$ PDB values for enamel and their latitudinal UK locale.

\begin{tabular}{llcc}
\hline LSB No & Locale & $\delta^{18} \mathrm{O}$ & Latitude \\
\hline 283 & Cumbria & -5.3 & 54.0 \\
288 & Dudley, Sutton Coalfield & -5.6 & 53.3 \\
LSB & BSE, Suffolk & -7.1 & 52.3 \\
289 & Essex & -6.2 & 52.0 \\
280 & Olney, Bucks & -6.4 & 51.6 \\
286 & Dartford, Kent & -6.8 & 51.5 \\
285 & East Ham, London & -6.6 & 51.5 \\
282 & SE, SW London & -5.4 & 51.5 \\
287 & Channel Islands, etc & -6.4 & 49.75 \\
\hline
\end{tabular}

a correction factor enabling PDB enamel values for horse and human to be compared directly to VSMOW precipitation values. The nature of mammalian metabolism of water and hence the fractionation of oxygen is known to vary between large and small mammals which drink on a daily basis from the same geographical locale (15). That horse and human are comparable in this study means that horse may be used as a proxy for human. However, just why horse and human $\delta^{18} \mathrm{O}$ values are comparable physiologically remains to be determined. Elegant work by Hoppe et al. $(33,34)$ investigated the relationship between extant feral horse enamel $\delta^{18} \mathrm{O}$ values and precipitation $\delta^{18} \mathrm{O}$, and found that horse values varied by one to three per mil to that of localized precipitation. They query the origin of the water source and their work underscores the complexity and importance of understanding and fully mapping the hydrological catchment for any study area or region.

This study has clearly illustrated that a UK range may be defined for 'exclusion' i.e. that values which fall outside of the UK range must relate to individuals who, during the period of tooth formation, were living at either a more northerly or more southerly locale to that of the U.K. The observed Icelandic value of $-10.2 \delta^{18} \mathrm{O}$ provided a value not seen in Darling et al's $(23,25-27)$ work, but is consistent with precipitation values recorded as an annual mean for Iceland (GNIP). Work by Soulsby et al. (22) have recorded annual means for precipitation and stream water $\delta^{18} \mathrm{O}$ values of $-10 \delta^{18} \mathrm{O}$ within a localized hydrological catchment in the Scottish Cairngorms upland area during winter months. The drilled samples taken for this study are not sufficient to resolve winter oxygen values, and upland horses were excluded to avoid any orographic effect. However, Soulsby et al.'s (22) work is cautionary for finer temporal sampling of enamel which may resolve enamel formation at a weekly or monthly level, where a winter contribution to mammalian drinking water may provide $\delta^{18} \mathrm{O}$ values which are at a distance from annual mean values for the same area, and hence lead to essentially a mapping error regarding locale at the point of enamel formation.

The forensic utility of isotopic tracking may be further pursued using this novel use of climate and hydrology. As mentioned, the majority of weather sweeps in from the Atlantic in a west to easterly direction $(23,25-27)$. Other weather systems do pass over the UK from easterly and south-westerly directions, but the prevailing pattern is from the Atlantic. As can be seen in Figure 1 the VSMOW $\delta^{18} \mathrm{O}$ values for precipitation are orientated vertically so that depletion increases west to east with repeated rain-out events. The most enriched values are dispersed along the western coastal regions of the UK including Ireland. What is interesting is that a potential exists to place individuals within the UK landscape, but what is clear from this study is that individuals may also be placed outside of the UK, where enamel oxygen val- 
ues could not be derived from UK precipitation, and therefore drinking water. This isotopic method therefore has some real utility as a human tracking tool within forensics and may be applied with other methods to refine a missing person search to an area/region and/or to provide other statements regarding global origin. Clearly, much work remains, and it is envisaged that oxygen depletion and enrichment geographical data contribute one piece of life history information alone, and further research to refine this tool and to extend to other isotopes is necessary. The establishment of reliable animal proxies is thus extremely important for furtherance of this aspect of forensic work so that regionalized hydrology may be properly understood particularly with reference to identification of a recharge potential from waters of mixed age e.g. aquifers and glacial melt. Additionally, human tissues, other than skeletal tissues, might usefully be examined since their temporal component will be constrained to a shorter physiological residence time.

\section{ACKNOWLEDGEMENTS}

The authors would like to thank staff at the Natural History Museum, London, who kindly donated their long treasured childhood tooth extractions to this study. Horse material was provided by the Natural History Museum, London, and by Keith Dobney. The isotopic work was undertaken at the Dept. Archaeology, University of Cape Town isotopic facility. Partial funding for this work was received from Glaxo Wellcome Foundation.

\section{REFERENCES}

1. Budd P. The distribution of lead within ancient and modern human teeth: Implications for long-term and historical exposure monitoring. Sci. Total Environ. 1998; 2-3: 121-136.

2. Montgomery J., Evans J.A., Neighbour T. Sr isotope evidence for population movement within the Hebridean Norse community of NW Scotland. J. Geol. Soc. 2003; 160: 649-653

3. White C., Longstaffe F.J., Law K.R. Exploring the effects of environment, physiology and diet on oxygen isotope ratios in ancient Nubian bones and teeth. Journal of Archaeological Science 2004; 31 : 233-350.

4. White C., Spence M.W., Longstaffe F.J., Law K.R. Demography and ethnic continuity in the Tlailotlacan enclave of Teotihuacan: the evidence from stable oxygen isotopes. Journal of Anthropological Archaeology 2004; 23: 385-403

5. Fricke H.C., O'Neil J.R., Lynnerup N. Oxygen isotope composition of human tooth enamel from medieval Greenland: linking climate and society. Geology 1995; 23: 869-872.

6. Tuross N., Behrensmeyer A.K., Eanes E.D., Fisher L.W., Hare P.E. Molecular preservation and crystallographic alterations in a weathering sequence of wildebeest bones. Applied Geochemistry 1989; 4: 261-270

7. Bell L.S., Boyde A., Jones S.J. Diagenetic alteration to teeth in situ illustrated by backscattered electron imaging. Scanning 1991; 13: 173-183.

8. Bell L.S., Skinner M.F., Jones S.J. The speed of post mortem change to the human skeleton and its taphonomic significance. Forensic Science International 1996; 82: 129-140.

9. Cerling T.E., Harris J.M., MacFadden B.J., Leakey M.G., Quade J., Eisenman V., et al. Global vegetation change through the Miocene/Pliocene boundary. Nature 1997; 389: 153-158.

10. Cerling T.E. Expansion of $\mathrm{C}_{4}$ as an indicator of global ecological change in the Late Miocene. Nature 1993; 361: 344-345.

11. Fricke H.C., O'Neil J.R. Inter- and intra-tooth variation in the oxygen isotope composition of mammalian tooth enamel phosphate: implications for palaeoclimatological and paleobiological research. Palaeogeography, Palaeoclimatology, Palaeoecology 1996; 126: 91-99.

12. Lindars E.S., Grimes S.T., Mattey D.P., Collinson M.E., Hooker J.J., Jones T.P. Phosphate $\delta^{18} \mathrm{O}$ determination of modern rodent teeth by direct laser fluorination: an appraisal of methodology and potential application to palaeoclimate reconstruction. Geochimica et Cosmochimica Acta 2001; 65: 5145-5148. 
13. Cerling T.E., Sharp Z.D. Stable carbon and oxygen analysis of fossil tooth enamel using laser ablation. Palaeogeography, Palaeoclimatology, Palaeoecology 1996; 126: 173-186.

14. Bell L.S., Cox G., Sealy J.C. Determining life history trajectories using bone density fractionation and stable light isotope analysis: a new approach. American Journal of Physical Anthropology 2001; 116: 66-79.

15. Lee-Thorp J.A., Sponheimer M. Opportunities and constraints for reconstructing palaeoenvironments from stable light isotope ratios in fossils. Geological Quarterly 2005; 49: 195-204.

16. Longinelli A. Oxygen isotopes in mammal bone phosphate: a new tool for paleohydrological and paleoclimatological research? Geochimica et Cosmochimica Acta 1984; 48: 385-390.

17. Luz B., Kolodny Y., Horowitz M. Fractionation of oxygen isotopes between mammalian bone-phosphate and environmental drinking water. Geochimica et Cosmochimica Acta 1984; 48: 1689-1693.

18. Ayliffe L.K., Chivas A.R. Oxygen isotope composition of the bone phosphate of Australian kangaroos: potential as a palaeoenvironmental recorder. Geochimica et Cosmochimica Acta 1990(54): 2603-2609.

19. Luz B., Cormie A.B., Schwarcz H.P. Oxygen isotope variations in phosphate of deer bones. Geochimica et Cosmochimica Acta 1990(54): 1723-1728.

20. Lee-Thorp J.A., Manning L., Sponheimer M. Exploring problems and opportunities offered by downscaling sample sizes for carbon isotope analyses of fossils. Bulletin de la Societè Geologique de France 1997; 168: 767-773

21. Bryant J.D., Froelich P.N., Showers W.J., Genna B.J. Biological and climatic signals in the oxygen isotopic composition of Eocene - Oligocene equid enamel phosphate. Palaeogeography, Palaeoclimatology, Palaeoecology 1996(126): 75-89.

22. Soulsby C., Malcom R., Helliwell R., Ferrier R.C., Jenkins A. Isotope hydrology of the Allta' Mharcaidh catchment, Cairgorms, Scotland: implications for hydrological pathways and residence times. Hydrological Processes 2000; 14: 747-762.

23. Darling W.G., Talbot J.C., Brownless M.A. Stable isotopic content of rainfall and groundwaters in the British Isles. IAEA Report 1996: 434-437.

24. Dansgaard W. Stable isotopes in precipitation. Tellus 1964; 16: 466-468

25. Darling W.G. The stable isotopic content of rainfall and groundwater in the British Isles. IAEA SM336/24P 1999.

26. Darling W.G., Bath A.H., Talbot J.C. The O \& H stable isotopic composition of fresh waters in the British Isles. 2. Surface waters and groundwater. Hydrology and Earth System Sciences 2003; 7(2): $183-195$

27. Darling W.G., Talbot J.C. The O \& H stable isotopic composition of fresh waters in the British Isles. 1. Rainfall. Hydrology and Earth System Sciences 2003; 7(2): 163-181.

28. Budd P., Millard A., Chenery C., Lucy S., Roberts C. Investigating population movement by stable isotope analysis: a report from Britain. Antiquity 2004; 78(299): 127-141.

29. McDonnell J.J., Stewart M.K., Owens I.F. Effects of catchment scale subsurface mixing on stream isotopic mixing. Water Resources Research 1991; 27: 3065-3073.

30. Ogunkoya Y.O., Jenkins A. Analysis of runoff pathways and flow contributions using deuterium and stream chemistry. Hydrological Processes 1991; 5: 271-282.

31. Jenkins A., Ferrier R.C., Harriman R., Ogunkoya Y.O. A case study in catchment hydrogeochemistry: conflicting interpretations from hydrogeological and chemical observations. Hydrological Processes 1994; 8: 335-349

32. Vitvar T., Balder W. Estimation of mean residence times and run-off generation by stable isotope measurements in a small pre-alpine catchment. Applied Geochemistry 1997; 12: 787-796

33. Hoppe K.A., Amundson R., Vavra M., McClaran M.P, Anderson DL. Isotopic anlaysis of tooth enamel carbonate from modern North American feral horses: implications for paleoenvironmental reconstructions. Palaeogeography, Palaeoclimatology, Palaeoecology 2004; 203: 299-311.

34. Hoppe K.A., Stover S.M., Pascoe J.R., Amundson R. Tooth enamel biomineralization in extant horses: implications for isotopic microsampling. Palaeogeography, Palaeoclimatology, Palaeoecology 2004; 206: $355-365$. 